\title{
A nostalgia como problema metahistórico: uma introdução
}

Nostalgia as a meta-historical problem: an interpretation

\author{
André de Lemos Freixo \\ andredelemos@gmail.com \\ Professor Adjunto \\ Universidade Federal de Ouro Preto \\ Rua do Seminário, s/n \\ 35420-000 - Mariana - MG \\ Brasil \\ Marcelo Santos de Abreu \\ orientacaoufop@gmail.com \\ Professor Adjunto \\ Universidade Federal de Ouro Preto \\ Rua do Seminário, s/n \\ 35420-000 - Mariana - MG \\ Brasil \\ Sérgio da Mata \\ sdmata@ichs.ufop.br \\ Professor Adjunto \\ Universidade Federal de Ouro Preto \\ Rua do Seminário, $\mathrm{s} / \mathrm{n}$ \\ 35420-000 - Mariana - MG \\ Brasil
}

138

Palavras-chave

Nostalgia; Modernidade; História.

Keywords

Nostalgia; Modernity; History.

Recebido em: 10/4/2017

Aprovado em: 2/5/2017 
A nostalgia faz parte do repertório básico de experiências humanas. Ela pode ser encontrada nas mais diferentes épocas e lugares, a despeito do esforço, não menos recorrente, de se lhe emprestar certo colorido local. As perspectivas sob as quais se pretendeu explicá-la e descrevê-la remontam ao alvorecer da ciência moderna. Desde Johannes Hofer, o interesse por esta mistura de idealização retrospectiva e topofilia tem ocupado gerações de estudiosos, de Jacob Grimm a Roberto DaMatta. Da Heimweh dos antigos mercenários suíços ao banzo dos africanos trazidos à força para o novo mundo, muito já se escreveu a respeito da nostalgia.

Os historiadores são em geral pouco interessados pelo fenômeno da nostalgia. Por vezes o termo "nostálgicos" é empregado no sentido de marcar os "conservadores", num movimento complexo no qual tais conceitos são empregados de modo intercambiável. Os textos a seguir, por nós traduzidos, procuram convidar os historiadores brasileiros a prestar a devida atenção à abertura de possibilidades - não só teóricas, mas políticas - sugerida pela leitura dos ensaios de Arnold Gehlen e Svetlana Boym.

Depois da grande leva de publicações nos últimos anos sobre as experiências de trauma coletivo, talvez seja chegada a hora de nos ocuparmos com modalidades menos extra-cotidianas de presença do passado. Ao contrário do que se convencionou a respeito do conceito de trauma, entendido como uma ferida aberta e uma dor que não passa, um "passado" que insiste em não passar, a nostalgia não carece de "tratamento". Ela não precisa ser trabalhada, reprimida ou sublimada, pois trata-se de um sentimento distinto da dor traumática, ela representa uma melancolia que, paradoxalmente, se sente com algum prazer.

Para além das tradicionais análises médicas, psicológicas e literárias do fenômeno, um de nossos autores traduzidos, Arnold Gehlen, propôs sua "interpretação histórico-política" da nostalgia numa época em que o tema aparentemente não fazia sentido algum no campo da sociologia. Publicado no ano de sua morte, este texto de 1976 destoa completamente do Zeitgeist daquela época, um momento em que o otimismo das filosofias da história ainda parecia amplamente amparado pelos fatos. Embora fosse um dos mais influentes intelectuais conservadores alemães (o que não impediu que Adorno, Lukács, Blumenberg, Luhmann e Honneth recorressem com frequência aos seus escritos), Gehlen nunca se notabilizou por uma sensibilidade especial em relação à história. Enquanto o outro grande nome da antropologia filosófica, Helmuth Plessner, caracteriza o ser humano como constitutivamente apátrida e como "uma questão em aberto", para Gehlen o humano é um ser de carências, e a cultura uma jaula feita de hábitos e instituições. Em Plessner o ser humano é todo possibilidade, e seu lugar um lugar utópico. Em Gehlen, ele é um ser carente de estabilidade e orientação. Ainda que as duas visões se complementem, é curioso que a nostalgia e o advento de surtos nostálgicos possam ser melhor compreendidos por meio da teoria daquele que, dentre os pais da antropologia filosófica, menos se interessou pela história. O conceito de posicionalidade excêntrica, cunhado por Plessner para descrever a condição humana, tanto quanto a tradicional noção de Bildung, encontram aqui os seus 
limites. Configurando-se como uma segunda natureza, a cultura exerce uma força centrífuga que nos reconduz e por vezes encarcera num espaço e tempo específicos (se idealizados ou não, pouco importa) cujo abandono é, não raro, doloroso. Para Gehlen o ser humano está condenado a essa dor, razão pela qual suas reflexões se iniciam pelo tema da felicidade. Nostalgia e utopia vivem às custas da ilusão de que a plenitude existiu, ou há de existir um dia.

Os estrategistas das indústrias do audiovisual e fonográfica, ao que parece, perceberam-no antes de nós. A entropia temporal que marca as sociedades contemporâneas se revela, entre outras coisas, no prestígio compensatório do vintage e do second hand, situação que o rapper Prinz Pi traduziu nesses versos: gostaríamos tanto de estar no ontem / vivemos segundo a fórmula "quanto mais retrô, mais novo". Recentemente, o cineasta brasileiro João Moreira Salles afirmou em entrevista que "a nostalgia mata". Ele se referia à visão dominante em certos meios, envolta numa densa névoa romântica, que ainda hoje cerca os eventos do maio de 1968. Tal juízo expressa uma dificuldade que não seria o caso de dramatizar. Por uma questão não apenas de princípios, mas também de empatia, os intelectuais conservadores estão muitas vezes mais próximos de compreender a nostalgia e inclusive de torná-la esteticamente produtiva. É o caso de Arnold Gehlen, que já em meados da década de 1960 defendia a tese de que o mundo contemporâneo passou por um processo de cristalização cultural, adentrando com isso a era da posthistoire. É também o caso de Andrei Tarkovski, cujo notável filme Nostalghia, de 1983, pode ser visto como a versão

140 cinematográfica dos diagnósticos de Gehlen. À época, um colunista do New York Times, se bem que com intenção crítica, resumiu Nostalghia em duas palavras: "nothing happens".

De um filme mais recente e de enorme sucesso, Adeus Lenin!, pode-se dizer outra coisa: tudo acontece novamente. Svetlana Boym lembra esse filme para indicar o artificialismo que pode constituir a cultura nostálgica contemporânea como resposta à crise de futuro experimentada nas últimas décadas. Em sua interpretação, ela se encontra com intelectuais conservadores e progressistas ao apontar a relevância do fenômeno para a compreensão do nosso mundo. Encontro revelado igualmente na identificação da nostalgia à modernidade, e especialmente o lugar que a utopia - a busca da felicidade, diria Gehlen ocupa no mundo moderno. No entanto, Boym distingue alguma positividade na nostalgia como fenômeno que não se reduz necessariamente a um passadismo compensatório - ao contrário de um intelectual progressista como Andreas Huyssen, que no mesmo momento fazia a crítica da produção mercantil da nostalgia como um indício de certo aprisionamento em um presente carregado de passados e carente de futuro.

O texto de Boym, que resume as principais hipóteses sobre a nostalgia desenvolvidas no livro The Future of Nostalgia (2001), se situa no campo de reflexão sobre o suposto fechamento do horizonte de expectativas na contemporaneidade. Reflexões que ensejaram os diagnósticos - a palavra aqui não é inocente - sobre o que seria a crise de futuro: ela estaria a indicar uma nova ordem do tempo, o presentismo como novo regime de historicidade ou 
o presente amplo como evidência de esgotamento do cronótopo historicista (para ficarmos apenas nas proposições que ganharam relevância entre nós). Boym partilha dessas percepções, algumas claramente nostálgicas, de certo mal estar na contemporaneidade provocado pela produção massiva de passados em nosso tempo.

O que ela traz de novo para o debate, porém, são as distintas possibilidades da cultura nostálgica contemporânea. Em um primeiro sentido, como já apontamos, a nostalgia é contemporânea da utopia como traço moderno e que precisa ser pensada em sua dimensão espaço-temporal. Por outro lado, Boym não a vê como necessariamente oposta à utopia - um dos mais instigantes insights em sua análise. A autora procura identificar duas modalidades da nostalgia: a restauradora e a reflexiva. Ambas transcendem diferentes paisagens e nomes próprios que a nostalgia possa ganhar. Realizam-se em diversos contextos políticos, intercambiam-se certamente, embora a autora não demonstre exatamente como isso se dá ao marcar as diferenças entre uma e outra. As duas produzem e atualizam formas estéticas próprias que configuram, por sua vez, contornos éticos precisos. Em sua prosa elegante, Boym nos faz ver que a nostalgia reflexiva assume a contingência e não procura deter a mudança, ao passo que a nostalgia restauradora evoca o passado, especialmente o passado grandioso das idades de ouro nacionais - diferença que parece hierarquizar cada uma delas na tipologia. A primeira "temporaliza o espaço", a segunda "espacializa o tempo", do que podemos inferir duas posturas distintas: ver num lugar, mesmo no desterro, as camadas de tempo e história que se misturam e podem inspirar o novo ou inscrever no presente a marca de um lugar pretérito hegemônico, sempre idêntico a si mesmo. A última quer fazer do presente um lugar para o futuro do passado, configurando, por assim dizer, uma utopia conservadora como aquela imaginada por Ernst Jünger em seu romance distópico Eumeswil, de 1987. A primeira, ao contrário, faz do passado uma inspiração para um futuro aberto, recobrando, talvez, o sentido das utopias futuristas e do "princípio esperança".

Não é o caso, nessa introdução, de nos estendermos muito no delineamento das características da nostalgia para os dois autores, nem de marcar as diferenças de fundo que há entre eles - o que de fato já se evidencia nessas notas breves. Esperamos que as leituras dos textos provoquem a reflexão sobre os passados presentes não apenas a partir do que já conhecemos e controlamos racionalmente, mas também a partir de um sentimento a que estamos naturalmente inclinados: a saudade. 